\title{
Mapping the Human Amylase Gene Cluster on the Proximal Short Arm of Chromosome 1 Using a Highly Informative (CA $)_{n}$ Repeat
}

\author{
Nicholas C. Dracopoli* and Miriam H. Meisler $†$ \\ *Center for Cancer Research and Department of Biology, Massachusetts Institute of Technology, 77 Massachusetts Avenue, \\ Cambridge, Massachusetts 02139; and †Department of Human Genetics, University of Michigan, Ann Arbor, Michigan 48109
}

Received November 16, 1989; revised January 23, 1990

The human amylase gene cluster includes a $(\mathrm{CA})_{n}$ repeat sequence immediately upstream of the $\gamma$-actin pseudogene associated with the AMY2B gene. Analysis of this $(\mathrm{CA})_{n}$ repeat by PCR amplification of genomic DNA from the 40 families of the Centre d'Etude du Polymorphisme Humain (CEPH) reference panel revealed extensive polymorphism. A total of six alleles with (CA) $n$ lengths of 16-21 repeats were found. The average heterozygosity for this polymorphism was 0.70. Multipoint linkage analysis showed that the amylase gene cluster is located distal to the nerve growth factor $\beta$-subunit gene (NGFB) and is within $1 \mathrm{cM}$ of the anonymous locus D1S10. The amylase (CA) $n$ repeat provides a convenient marker for both the physical and the genetic maps of human chromosome 1p. (1890 Academic Press, Inc.

\section{INTRODIJCTION}

The human amylase gene cluster spans $240 \mathrm{~kb}$ and includes two pancreatic amylase genes (AMY2A and AMY2B), three salivary amylase genes (AMY1A, $A M Y 1 B$, and $A M Y 1 C$ ), and a truncated pseudogene (AMYP1) (Gumucio et al., 1988; Samuelson et al., 1988; Groot et al., 1989). The amylase genes have been mapped to chromosome 1p21 (Munke et al., 1984; Tricoli and Shows, 1984; Zabel et al., 1983). Extensive analysis of this gene cluster revealed only two relatively uninformative RFLPs (Gumucio et al., 1985; Ishizaki et al., 1985). In a search for a more informative polymorphic marker in the amylase gene cluster, we have analyzed the $(\mathrm{dC}-\mathrm{dA})_{n} \cdot(\mathrm{dG}-\mathrm{dT})_{n}$ or $(\mathrm{CA})_{n}$ repeat sequence located 48 nucleotides upstream of the $\gamma$-actin pseudogene ACPGP3 and $2.3 \mathrm{~kb}$ upstream of AMY2B (Samuelson et al., 1990). Approximately $10^{5}$ copies of the tandemly repeated DNA (CA) $n$ sequences are interspersed throughout the human genome (Miesfield et al., 1981; Hamada and Kakunaga, 1982; Hamada et $a l$., 1982). These $(\mathrm{CA})_{n}$ repeats have recently been shown to be highly polymorphic (Weber and May, 1989; Litt and Luty, 1989) and provide a useful new source of polymorphisms for genetic analysis.

\section{MATERIALS AND METHODS}

\section{Families}

A total of 526 genomic DNA samples from the 40 families of the CEPH reference pedigrees (Dausset, $1986)$ were used in the analysis of the $(\mathrm{CA})_{n}$ repeat sequence in the human amylase gene cluster.

\section{PCR Analysis}

The $(\mathrm{CA})_{n}$ repeat which is located $5^{\prime}$ to the AMY2B gene (Fig. 1) occurs in an AT-rich region. The two primers were selected to maximize the GC content and, where possible, to have at least two G's or C's at the $3^{\prime}$ end of the oligonucleotide. The coding strand primer is a 25 -mer (5'-TATTTACTGTCCTTATTTATGTGGG $\left.-3^{\prime}\right)$. The noncoding strand primer is a 20 -mer $\left(5^{\prime}\right.$ AAACCTCTGGCAGTGTACAC-3'). Primers were synthesized by the University of Michigan Center for Molecular Genetics.

The coding strand primer was end-labeled for $30 \mathrm{~min}$ at $37^{\circ} \mathrm{C}$ in a $25-\mu \mathrm{l}$ reaction containing $20 \mu \mathrm{l}\left[\gamma^{3}{ }^{32} \mathrm{P}\right] \mathrm{ATP}$ $(6000 \mathrm{Ci} / \mathrm{mmol}), 1 \mu \mathrm{l}$ primer $(20 \mu M), 2.5 \mu \mathrm{l} 10 \times$ kinase buffer (1X $=50 \mathrm{mM}$ Tris (pH 7.6), $10 \mathrm{mM} \mathrm{MgCl}, 5$ $\mathrm{m} M$ DTT, $100 \mu M$ spermidine, $100 \mu M$ EDTA), and 1 $\mu \mathrm{l}$ T4 polynucleotide kinase $(50 \mathrm{U} / \mu \mathrm{l})$. The $\mathrm{T} 4$ polynucleotide kinase was inactivated by incubation at $65^{\circ} \mathrm{C}$ for $10 \mathrm{~min}$. The entire $25-\mu \mathrm{l}$ kinase reaction, without separating the unincorporated nucleotides, was added to sufficient buffer mix for 25 to 100 PCR reactions.

PCR was performed under standard conditions (Saiki et al., 1985, 1988) in $25-\mu$ l reactions containing $1 \mu \mathrm{l}$ genomic DNA template (200 ng), $1.25 \mu \mathrm{l}$ each oligonucleotide primer $(20 \mu M), 4 \mu \mathrm{dNTP} \operatorname{mix}(1.25$ mM each dA'TP, dCTP, dGTP, dT'TP), $2.5 \mu \mathrm{l} 10 \times$ PCR 


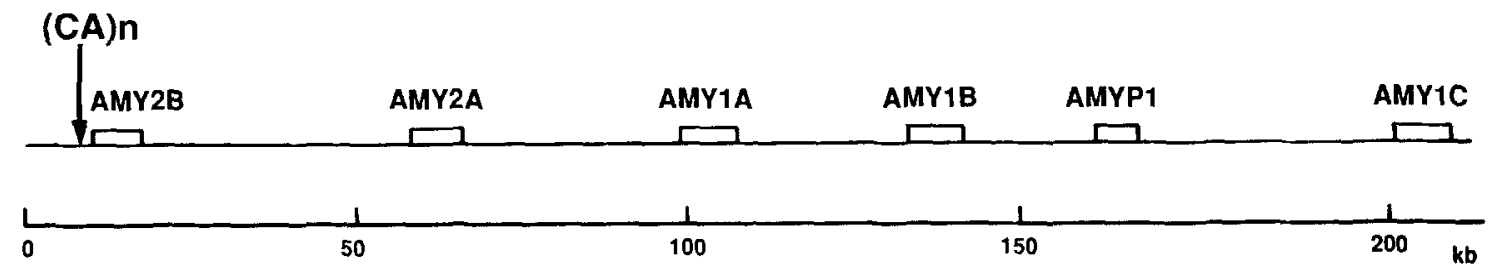

FIG. 1. The (CA $)_{n}$ repeat block is located $2.3 \mathrm{~kb}$ upstream of the human amylase gene cluster. This cluster includes two pancreatic amylase genes (AMY2A and AMY2B), three salivary genes (AMY1A, AMY1B, and AMY1C), and one truncated gene (AMYP1) (9, 11). Not shown but also present within the $240-\mathrm{kb}$ region are multiple copies of a $\gamma$-actin processed pseudogene and an endogenous retrovirus (31).

buffer $(1 \times=10 \mathrm{~m} M$ Tris $(\mathrm{pH} 8.3), 50 \mathrm{mM} \mathrm{KCl}, 1.5$ $\mathrm{mM} \mathrm{MgCl}{ }_{2}, 0.01 \%$ gelatin), $0.125 \mu$ l AmpliTaq DNA polymerase $(5 \mathrm{u} / \mu \mathrm{l})$, and $0.25-1.00 \mu \mathrm{l}$ primer end-labeling reaction mix. For amplification, each sample was denatured $\left(3 \mathrm{~min}\right.$ at $\left.94^{\circ} \mathrm{C}\right)$ and subjected to 30 amplification cycles (each cycle consisting of $2 \mathrm{~min}$ annealing at $55^{\circ} \mathrm{C}, 3$ min extension at $72^{\circ} \mathrm{C}$, and 1 min denaturing at $94^{\circ} \mathrm{C}$ ) in a Perkin-Elmer-Cetus thermal cycler. The amplified DNA was run on $8 \%$ acrylamide sequencing gels. The gels were not dried, but only covered with a thin plastic film and exposed at $-70^{\circ} \mathrm{C}$ to Kodak XAR5 film for 2-24 h.

The sizes of the $(\mathrm{CA})_{n}$ repeats in the genomic DNA samples were determined by comparison with that of a cloned $(\mathrm{CA})_{21}$ repeat from this region (Samuelson et al., 1990).

\section{Linkage Analysis}

Genotypes of the AMY2B (CA) ${ }_{n}$ repeat were entered into a database containing genotypes from a large number of chromosome 1 polymorphisms typed on the CEPH pedigrees (Dracopoli et al., 1988b; O'Connell et $a l ., 1989)$. The $\alpha$-satellite centromeric repeat polymorphism (D1Z5) (Waye et al., 1987) genotypes in the CEPH database (M. Mahtani, R. Lafreniere, and H. Willard, unpublished data) were used with permission of Dr. H. Willard. Initial analyses and data checking were carried out using the CEPH software package. The AMY2B $(\mathrm{CA})_{n}$ genotypes were converted into MAPMAKER (Lander et al., 1987) format using the LNKTOMAP program provided by Dr. K. Buetow. All two-point and multipoint linkage analyses were performed using MAPMAKER. All analyses were performed on a SUN 386i workstation.

\section{RESULTS}

\section{Polymorphism at the AMY2B (CA $)_{n}$ Repeat}

The $(\mathrm{CA})_{n}$ repeat is located $2.3 \mathrm{~kb}$ upstream of the AMY2B locus at the $5^{\prime}$ end of the amylase gene cluster (Fig. 1). To detect polymorphism, we used PCR primers corresponding to sequences on either side of the $(\mathrm{CA})_{n}$ repeat. The resulting pattern of amplified DNA consisted of multiple bands of varying intensity (Fig. 2).
These multiple bands have been detected in other $(\mathrm{CA})_{n}$ repeats and are presumed to be the result of the polymerase "stuttering" as it synthesizes the complementary strand of the $(\mathrm{CA})_{n}$ repeat during the PCR amplification (Weber and May, 1989). Homozygotes contain a single intense band with approximately four additional bands of diminishing intensity decreasing in size in single nucleotide steps (see lane 2 in Fig. 2). The largest band is always the most intense band in homozygotes. Heterozygotes contain two series of bands. These are easy to distinguish when the alleles differ in size by at least 4 nucleotides. However, the series of bands are superimposed in heterozygotes where the allele sizes differ by only 2 nucleotides. In these cases, it is possible to identify heterozygotes by the relative band intensities resulting from the superimposition of bands from the smaller allele on the trailing bands of the larger allele (see lane 1 in Fig. 2).

Six alleles were identified in the 526 samples of the CEPH pedigree (Table 1). The sizes of these alleles all differed by 2 nucleotides, suggesting that each allele

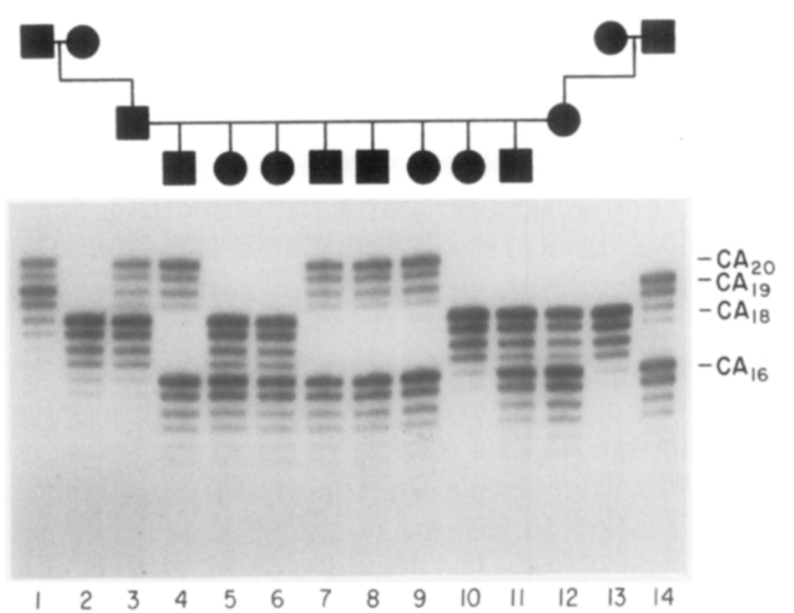

FIG. 2. (CA $)_{n}$ genotypes in CEPH family 1323 . The pedigree is superimposed above the gel and the number of dinucleotide repeats in each allele is indicated on the right. The genotypes (defined by the number of $\mathrm{CA}$ dinucleotides) for each individual in the pedigree are as follows: Lane $1,19 / 20 ; 2,18 / 18 ; 3,18 / 20 ; 4,16 / 20 ; 5,16$ / $18 ; 6,16 / 18 ; 7,16 / 20 ; 8,16 / 20 ; 9,16 / 20 ; 10,18 / 18 ; 11,16 / 18 ; 12$, $16 / 18 ; 13,18 / 18 ; 14,16 / 19$. 
TABLE 1

\begin{tabular}{ll}
$\begin{array}{c}\text { Allele Frequencies of the } \\
\text { at the AMY2B Locus }\end{array}$ \\
\hline$(\mathrm{CA})_{n}$
\end{tabular}

Note. The allele frequencies were determined by typing all 80 parents of the CEPH reference panel.

was generated by the gain or loss of a single CA dinucleotide. The amplified product between the two primers varied between 76 and 86 nucleotides. Complete concordance with Mendelian segregation was observed in all 40 of the CEPH families, and at least one parent was heterozygous in 38 families. The alleles ranged in size from $(\mathrm{CA})_{16}$ to $(\mathrm{CA})_{21}$. The allele frequencies are not evenly distributed, and the three intermediate repeats, sizes $(\mathrm{CA})_{18-20}$, account for approximately $90 \%$ of the alleles at this locus. The observed heterozygosity at this locus was 0.70 and the polymorphic information content (Botstein et al., 1980) was 0.63 . The allele frequencies did not differ from Hardy-Weinberg equilibrium $\left(\chi^{2}=8.31, P>0.99\right)$. The genotypes of the AMY2B (CA) $n$ repeat in the 40 CEPH reference families have been deposited in the CEPH database.

\section{Linkage Analysis}

Preliminary two-point linkage analysis showed strong linkage for the AMY2B (CA $)_{n}$ repeat with a large number of markers from proximal 1p (Table 2). The closest marker appeared to be locus D1S10, which showed only $1 \%$ recombination with a Lod score of 32.8. In the first stage of multipoint analysis, the AMY2B $(\mathrm{CA})_{n}$ polymorphism was tested against a fixed map of chromosome 1 that had been developed using the CEPH families (Dracopoli et al., 1988b; O'Connell et al., 1989). This analysis showed that AMY2B was located very close to D1S10 in the interval between D1S12 and D1S14. The relative orientation of AMY2B and D1S10 could not be determined.

The multipoint map of this region was recalculated after the addition of the AMY2B $(\mathrm{CA})_{n}$ polymorphism because the addition of a highly informative locus to a fixed map may affect the distances and relative order of tightly linked loci. The 120 possible orders of AMY2B, D1S9, D1S10, D1S12, and D1S14 were compared while four distal loci (PGM1, D1S22, D1S16, D1S20) and four proximal loci (D1S11, TSHB, NGFB,
TABLE 2

Summary of Two-Point Lod Scores for the AMY2B (CA) $n$ Repeat and 14 Polymorphic Loci from Proximal Chromosome 1p

\begin{tabular}{llllr}
\hline Locus & $\theta$ & $\theta_{\mathrm{m}}$ & $\theta_{\mathrm{f}}$ & LOD \\
\hline D1S9 & 0.09 & 0.03 & 0.14 & 27.08 \\
D1S10 & 0.01 & 0.02 & 0.01 & 32.82 \\
D1S11 & 0.13 & 0.04 & 0.17 & 16.09 \\
D1S12 & 0.06 & 0.02 & 0.10 & 20.49 \\
D1S13 & 0.22 & 0.25 & 0.20 & 7.34 \\
D1S14 & 0.08 & 0.12 & 0.04 & 26.01 \\
D1S16 & 0.21 & 0.25 & 0.20 & 6.82 \\
D1S20 & 0.11 & 0.13 & 0.10 & 6.14 \\
D1S22 & 0.38 & 0.36 & 0.40 & 0.54 \\
NGFB & 0.14 & 0.05 & 0.22 & 24.69 \\
NRAS & 0.11 & 0.05 & 0.25 & 19.12 \\
PGM1 & 0.36 & 0.30 & 0.50 & 2.28 \\
TSHB & 0.17 & 0.12 & 0.21 & 20.98 \\
\hline
\end{tabular}

NRAS) were held constant (Table 3). This analysis showed that the addition of the AMY2B $(\mathrm{CA})_{n}$ repeat affected the relative orientation of the two nearest proximal loci (D1S10 and D1S14). Previous analysis of this region tentatively placed D1S14 less than $2 \mathrm{cM}$ distal to D1S10 with support levels less than 100:1 (Dracopoli et al., 1988b). The inclusion of AMY2B in this map reverses the orientation of D1S14 and D1S10 and provides strong support ( $>5000: 1)$ that the tightly linked cluster of D1S10-AMY2B is located distal to D1S14 (Table 3). The relative orientation of AMY2B and D1S10 cannot be resolved. Examination of the CEPH families shows only two recombinants between AMY2B and D1S10 in individuals 1332-03 and 140803. The multipoint map of proximal chromosome $1 p$ is shown in Fig. 3.

\section{DISCUSSION}

A human amylase serum polymorphism was originally mapped to chromosome 1 by linkage to the un-

TABLE 3

Multipoint Analysis of the Four Most Likely Orders of AMY2B, D1S9, D1S10, D1S12, and D1S14

\begin{tabular}{cc}
\hline Possible orders & Relative likelihood \\
\hline D1S12-AMY2B-D1S10-D1S14-D1S9 & - \\
D1S12-D1S10-AMY2B-D1S14-D1S9 & $1: 1.4$ \\
D1S12-AMY2B-D1S14-D1S10-D1S9 & $1: 7,390.1$ \\
D1S10-AMY2B-D1S12-D1S14-D1S9 & $1: 18,505.9$ \\
\hline
\end{tabular}

Note. These orders were determined by calculating the 120 possible orders of the five loci (AMY2B, D1S9, D1S10, D1S12, and D1S14) while the locations of the four distal (PGM1-D1S22-D1S16-D1S20) and the four proximal markers (D1S11-TSHB-NGFB-NRAS) were held constant. 


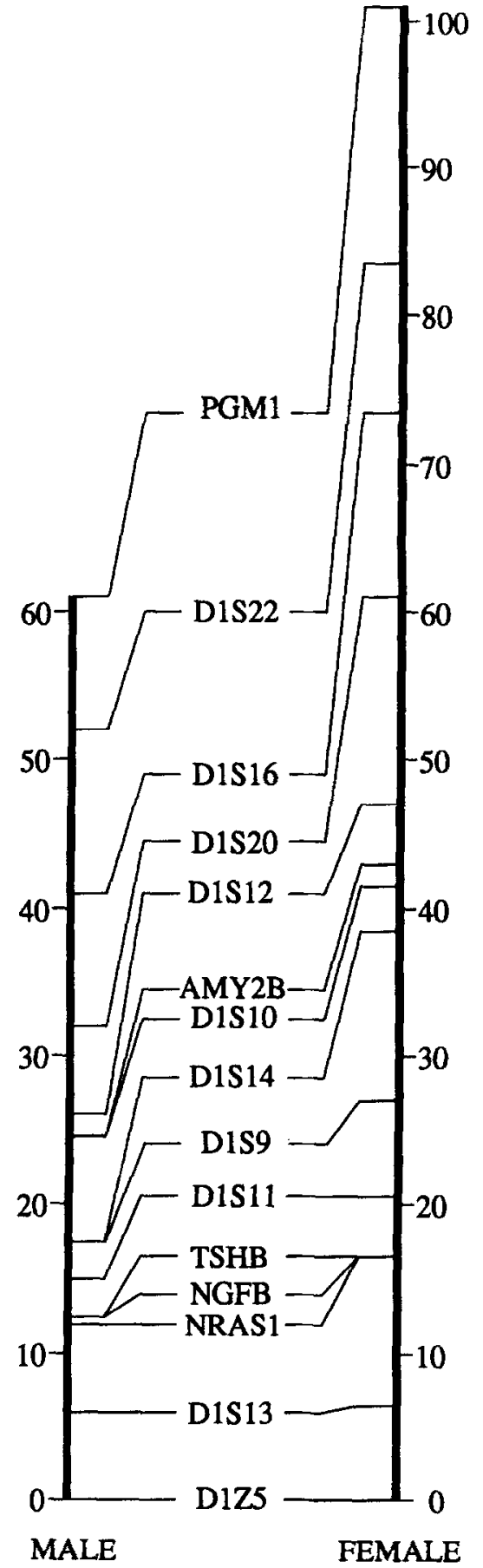

FIG. 3. Multipoint linkage map of proximal chromosome 1p from PGM1 to D1Z5. The recombination rates in each interval were permitted to differ between sexes, and the map distances are calculated using the Kosambi mapping function. The most favored map order is presented.

coiler region (Kamaryt et al., 1971) and to the Duffy blood group locus (Hill et al., 1972; Merritt et al., 1972, 1973). Assignment to the pericentromeric region of chromosome 1 was based on linkage analysis of a variety of blood group antigens, red cell enzymes, and serum proteins (Robson and King, 1984; Sherman et al., 1984; Wedd, 1984). The position of the amylase cluster was refined to $1 \mathrm{p} 21-\mathrm{p} 22$ by Southern blot analysis of somatic cell hybrids (Tricoli and Shows, 1984; Munke et al., 1984) and localized to $1 \mathrm{p} 21$ by in situ hybridization (Zabel et al., 1983; Munke et al., 1984).

The map of the proximal region of chromosome 1 has been confused for a number of years by conflicting physical assignments of the genes for the $\beta$-subunit of nerve growth factor (NGFB), the $\beta$-subunit of thyroid stimulating hormone (TSHB), and the neuroblastoma RAS viral oncogene homolog (NRAS). NGFB has been assigned to 1p22.1 (Zabel et al., 1985; Francke et al., 1983; Munke et al., 1984) and to 1p13 (Garson et al., 1987). TSHB has been assigned to $1 \mathrm{p} 22$ (Dracopoli et al., 1986) and has been shown to be on the same 310kb $S f$ fragment as NGFB (Dracopoli et al., 1988a). NRAS has been assigned to 1p13 (Davis et al., 1984; Garson et al., 1987) and to 1p22 (Munke et al., 1984).

It is evident from linkage analysis and pulsed-field gel electrophoresis that TSHB, NGFB, and NRAS form a very tightly linked gene cluster and that they must all be assigned to the same chromosomal band. Their location proximal to the AMY2B gene in $1 \mathrm{p} 21$, and close linkage to the $\alpha$-satellite centromeric repeat (D1Z5) (Fig. 3) provide strong evidence that the correct assignment for these three loci is $1 \mathrm{p} 13$ and not $1 \mathrm{p} 22$. Therefore the independent assignments of TSHB (Dracopoli et al., 1986) and NGFB and NRAS (Munke et al., 1984) to $1 \mathrm{p} 22$ are most likely incorrect. TSHB was assigned to chromosome $1 \mathrm{p} 22$ by analysis of somatic cell hybrids with breakpoints on proximal $1 p$. The proximal breakpoint was defined by cell line A9/ 1492. It seems likely that the cytogenetic analysis of this hybrid was incorrect and that A9/1492 contains the region 1p13-pter and does not break in 1p21 as previously thought (Rettig el al., 1984, 1986; Dracopoli et al., 1986, 1988a,b). Consequently, chromosomal assignments based on this breakpoint should be redefined and the smallest region of overlap (SRO) for the loci MSK1 (Rettig et al., 1984, 1986), D1S9, D1S10, D1S11, D1S12, D1S13, D1S14 (Dracopoli et al., 1988b), and TSHB (Dracopoli et al., 1986) should be extended to cover the region 1p22-p13. Examination of the linkage map of chromosome 1 further demonstrates that TSHB and D1S13 should be assigned to $1 \mathrm{p} 13$ and that D1S9, D1S10, D1S11, D1S12, and D1S14 should be assigned to $1 \mathrm{p} 13-\mathrm{p} 22$.

The amylase gene cluster has been the site of multiple insertions, deletions, and duplications during primate evolution (Samuelson et al., 1990). The paucity of RFLPs detected with amylase probes may reflect the recent origin of multiple gene copies from a single ancestral gene. The high PIC of the amylase-associated $(\mathrm{CA})_{n}$ repeat demonstrates the utility of this type of variation for human linkage studies, as was proposed in two recent reports (Weber and May, 1989; Litt and 
Luty, 1989). The detection of (CA $)_{n}$ polymorphism by PCR is faster, less laborious, and less expensive, requires less genomic DNA, and is likely to be more informative than the standard analysis of RFLPs by Southern blotting. These practical advantages justify an effort to identify additional polymorphisms of this type for use in human linkage analyses.

It has recently been suggested that the physical map of the human genome could be anchored by a reference set of PCR primers that detect unique sites in the human genome (Olson et al., 1989). The primers described here can serve this function both as an anchor point for the physical map of chromosome $1 p$ and as a connection to the linkage map of $1 \mathrm{p}$ through the $(\mathrm{CA})_{n}$ polymorphism.

\section{ACKNOWLEDGMENTS}

We are grateful to the CEPH for providing genomic DNA samples from the reference pedigree panel and thank Dr. Huntington Willard for permission to use data on the D1Z5 genotypes in the CEPH panel before publication. We also thank Dr. David Housman for his support and Drs. Daniel Haber, Sharon Graw, Alan Buckler, Hiroyuki Aburatani, and Linda Samuelson for their advice on PCR techniques. This work was supported by National Institutes of Health Grants CA-44176 (N.C.D.) and GM-24872 (M.H.M.).

\section{REFERENCES}

1. Botstein, D., White, R. L., SKolnick, M., AND DAvis, R. W. (1980). Construction of a genetic linkage map in man using restriction fragment length polymorphisms. Amer. J. Hum. Genet. 32: 314-331.

2. Dausset, J. (1986). Le Centre d'Etude du Polymorphisme Humain. La Presse Medicale 15: 1801-1802.

3. Davis, M., Malcolm, S., and Hall, A. (1984). The N-ras oncogene is located on the short arm of chromosome 1. Cytogenet. Cell Genet. 37: 448-449.

4. Dracopoli, N. C., Rettig, W. J., Whitfield, G. K., DaRLINGTON, G. J., SPENGleR, B. A., BIEDLER, J. L., OLD, L. J., AND KoURIDES, I. A. (1986). Assignment of the gene for the $\beta$ subunit of thyroid stimulating hormone to the short arm of chromosome 1. Proc. Natl. Acad. Sci. USA 83: 1822-1826.

5. Dracopoli, N. C., Rose, E., Whitfield, G. K., Guidon, P. T., Bale, S. J., Chance, P. A., Kourides, I. A., AND HousMAN, D. E. (1988a). Two thyroid hormone regulated genes, the $\beta$-subunits of nerve growth factor (NGFB) and thyroid stimulating hormone (TSHB), are located less than $310 \mathrm{~kb}$ apart in both human and mouse genomes. Genomics 3: 161-167.

6. Dracopoli, N. C., Stanger, B. Z., ITo, C. Y., Call, K. M., LiNCOLN, S. E., LANDER, E. S., AND HousMaN, D. E. (1988b). A genetic linkage map of 27 loci from PND to FY on the short arm of human chromosome 1. Amer. J. Hum. Genet. 43: 462470.

7. Francke, U., de Martinville, B., Coussens, L., and UlLRICH, A. (1983). The human gene for the beta subunit of nerve growth factor is located on the proximal short arm of chromosome 1. Science 222: 1248-1251.

8. GArson, J. A., VAN DEN BERghe, J. A., AND Kemshead, J. T (1987). Novel non-isotopic in situ hybridization technique detects small $(1 \mathrm{~kb})$ unique sequences in routinely G-banded human chromosomes: Fine mapping of $\mathrm{N}$-myc and $\beta$-NGF genes. Nucleic Acids Res. 15: 4761-4770.
9. Groot, P. C., Bleeker, M. J., Pronk, J. C., ARWert, F., MAGER, W. H., Planta, R. J., ERIKSSON, A. W., aNd Frants, R. R. (1989). The human $\alpha$-amylase multigene family consists of haplotypes with variable numbers of genes. Genomics 5: 2942.

10. GuMucio, D. L., MeISLER, M. H., AND KIDD, J. R. (1985). Detection of two RFLPs near the human salivary amylase gene on the short arm of chromosome 1. Amer. J. Hum. Genet. 37: A155.

11. Gumucio, D. L., Wiebauer, K., Caldwell, R. M., Samuelson, R. C., AND MEISLER, M. H. (1988), Concerted evolution of human amylase genes. Mol. Cell. Biol. 8: 1197-1205.

12. Hamada, H., and KaKunaga, T. (1982). Potential Z-DNA forming sequences are highly dispersed in the human genome. Nature (London) 298: 396-398.

13. Hamada, H., Petrino, M. G., and Kakunaga, T. (1982). A novel repeated element with Z-DNA forming potential is widely found in evolutionary diverse eukaryotic genomes. Proc. Natl. Acad. Sci. USA 79: 64656469.

14. HILl, C. J., Rowe, S. I., AND LovrIEN, E. W. (1972). Probable genetic linkage between human serum amylase (Amy2) and Duffy blood group. Nature (London) 235: 162-163.

15. IshizaKi, K., NodA, A., IKenaga, M., IDA, K., OMOTO, K., NAKAMURA, Y., AND MATSUBARA, K. (1985). Restriction fragment length polymorphism detected by human salivary amylase cDNA. Hum. Genet. 71: 261-262.

16. Kamaryt, J., AdameK, R., AND VRBa, M. (1971). Possible linkage between uncoiler chromosome Un 1 and amylase polymorphism Amy 2 loci. Hum. Genet. 11 : 213-220.

17. LANDER, E. S., GreEN, P., ABRahamson, J., BARlow, A., DALY, M. J., LINCOLN, S. E', AND NEWBURG, L. (1987). Mapmaker: An interactive computer package for constructing primary genetic linkage maps of experimental and natural populations. Genomics 1: 174-181.

18. LITT, M., AND LUTY, J. A. (1989). A hypervariable microsatellite revealed by in vitro amplification of a dinucleotide repeat within the cardiac muscle actin gene. Amer. J. Hum. Genet. 44: 397401.

19. MerRitT, A. D., LovRIEN, E. W., Rivas, M. L., AND ConNeAly, P. M. (1973). Human amylase loci: Genetic linkage with the Duffy blood group locus and assignment to linkage group I. Amer. J. Hum. Genet. 25: 523-538.

20. MERRITT, A. D., Rrvas, M. L., AND WARD, J. C. (1972). Evidence for close linkage of human amylase loci. Nature New Biol. 239: 243-244.

21. Miesfield, R., Krystal, M., AND ARnheim, M. (1981). A member of a new repeated sequence family which is conserved throughout eukaryotic evolution is found between the human delta and beta globin genes. Nucleic Acids Res. 9: 5931-5947.

22. Munke, M., LindGRen, V., De-MakTinVILLe, B., AND FrANCKE, U. (1984). Comparative analysis of mouse-human hybrids with rearranged chromosomes 1 by in situ hybridization and Southern blotting: High resolution mapping of NRAS, NGFB, and AMY on human chromosome 1. Somat. Cell Mol. Genet. 10: 589-599.

23. O'Connell, P., Lathrop, G. M., Nakamura, Y., Leppert, M. L., ARDINGFr, R. H., MurRay, J. L., I.ALOUJEL, J.-M., AND WHITE, R. (1989). Twenty-eight loci form a continuous linkage map of markers for human chromosome 1. Genomics 4: 12-20.

24. Olson, M., Hood, L., Cantor, C., AND Botstein, D. (1989). A common language for physical mapping of the human genome. Science 245: 1344-1345.

25. RetTig, W. J., Dracopoli, N. C., Goetzger, T. A., SPENGler, 
B. A., Biedler, J. L., OETTGEN, H. F., AND OLD, L. J. (1984). Two cell surface markers for human chromosome 1 in interspecies hybrids. Somat. Cell Mol. Genet. 10: 297-305.

26. Rettig, W. J., Dracopoli, N. C., Spengler, B. A., Kersey, J. H., BIEDLER, J. L., AND OLD, L. J. (1986). Cell-surface antigens determined by human chromosomes 1 and 12: Comparative serological and somatic cell genetic analysis of eight antigenic systems. Somat. Cell Mol. Genet. 12: 33-40.

27. Robson, E. B., AND KING, J. (1984). Family data on sixteen chromosome 1 loci. Ann. Hum. Genet. 48: 347-358.

28. Saiki, R. K., Gelfand, D. H., STOFFEL, S., SchaRF, S. J., HIGuCHI, R., HoRn, G. T., Mullis, K. B., AND EhrLICH, H. A. (1988). Primer directed enzymatic amplification of DNA with a thermostable DNA polymerase. Science 239: 487-491.

29. SaIKI, R. K., Scharf, S., Faloona, F., Mullis, K. B., HorN, G. T., AND ARNHEIM, N. (1985). Enzymatic amplification of $\beta$ globin genomic sequences and restriction site analysis for diagnosis of sickle cell anemia. Science 230: 1350-1354.

30. Samuelson, L. C., Wiebauer, K., Gumucio, D. L., and MeisLER, M. H. (1988). Expression of the human amylase genes: Recent origin of a salivary amylase promoter from the actin pseudogene. Nucleic Acids Res. 16: 8261-8275.

31. Samuelson, L. C., Wigbauer, K., SNow, C. M., AND Meisler, M. H. (1990). Retroviral and pseudogene insertion sites reveal the lineage of human salivary and pancreatic amylase genes from a single gene during primate evolution. Mol. Cell. Biol., in press.
32. Sherman, S. L., KInG, J., RoBson, E. B., AND YeE, S. (1984). A revised map of chromosome 1. Ann. Hum. Genet. 48: 243251.

33. Tricoli, J. V., AND SHows, T. B. (1984). Regional assignment of human amylase (AMY) to p22-p21 of chromosome 1. Somat. Cell. Mol. Genet. 10: 205-210.

34. Waye, J. S., Durfy, S. J., Pinkel, D., Kenwrick, S., PatTERSON, M., DAVIES, K. E., AND WILlARD, H. F. (1987). Chromosome-specific alpha satellite DNA from human chromosome 1: Hierarchical structure and genomic organization of a polymorphic domain spanning several hundred kilobase pairs of centromeric DNA. Genomics 1: 43-51.

35. WEBER, J. L., AND MAY, P. E. (1989). Abundant class of human DNA polymorphisms which can be typed using the polymerase chain reaction. Amer. J. Hum. Genet. 44: 388-396.

36. WEDD, N. (1984). A computer program for constructing a maximum-likelihood map from linkage data and its application to human chromosome 1. Ann. Hum. Genet. 48: 333-345.

37. Zabel, B. U., Naylor, S. L., SaKaguchi, A. Y., Bell, G. I., AND SHOWs, T. B. (1983). High resolution chromosomal localization of human genes for amylase, proopiomelanocortin, somatostatin, and a DNA fragment (D3S1) hy in situ hybridization. Proc. Natl. Acad. Sci. USA 80: 6932-6936.

38. ZaBel, B. U., EdDY, R. L., LaLley, P. A., ScotT, J., Bell, G. I., AND SHows, T. B. (1985). Chromosomal localizations of the human and mouse genes for the precursors of epidermal growth factor and the $\beta$-subunit of nerve growth factor. Proc. Natl. Acad. Sci. USA 82: 469-473. 